\title{
PENERAPAN MEDIA MUSIKALISASI PUISI TERHADAP PENINGKATAN KEMAMPUAN MENGAPRESIASI PUISI SISWA $X$ MIPA3 SMAN 87 JAKARTA
}

\author{
Khaerunnisa ${ }^{1}$ Muhammad Nasir ${ }^{2}$ \\ Universitas Muhammadiyah Jakarta
}

\begin{abstract}
ABSTRAK
Penelitian ini bertujuan untuk mendeskripsikan peningkatan kemampuan apresiasi puisi siswa kelas X SMAN 87 Jakarta pada mata Pelajaran Bahasa dan Sastra Indonesia melalui penerapan media musikalisasi puisi. Subjek penelitian yang yang dikenai tindakan adalah siswa kelas X MIPA3 SMAN 87 Jakarta tahun ajaran 2016/2017. Desain penelitian yang digunakan adalah Penelitian Tindakan Kelas (PTK). Prosedur pelaksanaan tindakan dan implementasi di lokasi penelitian terbagi dalam dua siklus. Pada siklus pertama, implementasi tindakan dengan menggunakan media musikalisasi puisi dilaksanakan satu kali pertemuan. Siklus II menggunakan desain yang sama seperti desain pembelajaran yang dilakukan pada siklus I. Pada setiap siklus lebih menekankan pada aspek-aspek yang membangun musikalisasi dalam apresiasi. Setelah siklus I dan II dilaksanakan, diadakan posttest. Posttest dilaksanakan untuk membandingkan hasil pembelajaran dengan media musikalisasi puisi. Hasil penelitian menunjukkan adanya peningkatan kemampuan apresiasi puisi. Hal tersebut dapat dilihat dari hasil prasiklus, siklus I dan siklus II. Pertama, berdasrkan prasiklus di peroleh hasil dengan nilai rata-rata 43,4. Kedua, berdasarkan siklus I diperoleh hasil dengan nilai rata-rata 74,4. Ketiga, berdasarkan siklus II diperoleh nilai rata-rata 83,25. Hal ini menunjukkan peningkatan kemampuan apresiasi siswa setelah dilaksanakan media musikalisasi puisi.
\end{abstract}

Kata Kunci: Apresiasi, Puisi, dan Media Musikalisasi 


\section{PENDAHULUAN}

astra sebagai bagian dari mata pelajaran
bahasa Indonesia memiliki fungsi
utama memperluas wawasan, peningkatan kepekaan rasa kemanusiaan, dan kepedulian sosial, menumbuhkan apresiasi budaya dan penyalur gagasan, imajinasi dan ekspresi secara kreatif dan kontruktif, baik secara lisan maupun tertulis. Melalui sastra siswa diajak untuk memahami, menikmati, dan menghayati karya sastra. Sastra dengan segala dimensinya juga telah menciptakan berbagai disiplin yang tidak akan pernah habis untuk dikaji, dari waktu ke waktu sastra senantiasa berkembang mengikuti kemampuan daya pikir manusia dan imajinasinya. Begitu juga dengan penelitian tentang pembelajaran sastra telah banyak dilakukan. Hal ini terbukti dengan banyaknya karya tulis ilmiah yang mengupas tentang pembelajaran sastra baik desain, media, maupun proses pembelajarannya. Berbagai persoalan yang muncul dalam memahami dan menyampaikan karya sastra selalu memunculkan hal-hal yang menarik untuk diteliti lebih lanjut, sehingga bisa menambah luasnya disiplin ilmu tentang pembelajaran sastra.

Sikap penghargaan dan kecintaan terhadap karya sastra dapat ditunjukkan, misalnya dengan perilaku gemar menciptakan karya sastra, gemar membicarakan dan mendengarkan karya sastra, gemar membaca karya sastra, gemar membicarakan karya sastra yang dibacanya atau didengarnya, gemar mengumpulkan buku-buku sastra. Dengan demikian bahwa tujuan dari pengajaran sastra itu mengarah pada sastra yaitu pengalaman kemanusian atau pengalaman sastra yang salah satunya bisa dipengaruhi dengan kegiatan mengapresiasi karya sastra. Mengapresiasi karya sastra merupakan kekuatan penting untuk menumbuhkan sikap kritis, pribadi yang terbatas dari emosi, dan akan membentuk sikap hidup yang lebih bahagia bagi diri sendiri dan orang lain. Oleh karena itu, pembelajaran apresiasi sastra diberikan pada siswa untuk menumbuhkan sikap positif tersebut.

Salah satu bentuk karya sastra adalah puisi. Karya sastra yang berbentuk puisi merupakan karya sastra yang tersaji secara monolog, menggunakan kata-kata yang indah dan kaya akan makna (Kosasih, 2008:31). Puisi merupakan pernyataan perasaan yang imajinatif, yaitu perasaan yang direkakan. Perasaan dan pikiran penyair yang masih abstrak dikonkretkan. Puisi tak lepas dari seni rangkai kata yang penuh dengan makna. Penyair mengolah kata sedemikian rupa sehingga tercapai puisi.

Puisi merupakan salah satu media bagi seseorang untuk mencurahkan segala macam perasaan yang ada di benaknya. Jadi, di dalam sebuah puisi, penyair mencurahkan segala perasaan dan pikirannya. Pikiran dan perasaan itu diramu dengan memanfaatkan kreatifitas penyair, kemudian diwujudkan melalui medium bahasa. Bahasa yang digunakan pun khas, berbeda dengan bahasa yang dipakai dalam drama dan fiksi, karena penyair ingin mengekspresikan pengalaman jiwanya secara padat dan intens. Apresiasi puisi sendiri dalam perkembangannya telah mengalami berbagai kemajuan, berbagai kalangan telah melakukan eksperimen terhadap apresiasi puisi ini supaya bisa lebih mudah untuk diterapkan dan dipahami cara kerjanya. Menurut Kamus Webster New 
International dalam (Salad, 2015:66) menyebutkan, bahwa apresiasi merupakan aktivitas manusia untuk menghormati, memberi putusan atau penilaian terhadap karya seni. Sementara dalam Kamus Hornby (dalam Salad 2015:66) Apresiasi di artikan sebagai: proper understanding and recognition (pemahamana dan pengenalan yang tepat), Judgment (pertimbangan), evaluation (penilaian), statemen giving valuation (pernyataan yang memberikan penilaian).Untuk dapat mengapresiasi puisi, siswa memerlukan pengenalan dan pengetahuan tentang puisi. Pengenalan dan pengetahuan tentang puisi ini dapat diperoleh siswa melalui kegiatan berlatih mengapreiasi puisi. Melalui kegiatan apresiasi puisi siswa dapat mengenal, menggemari, menikmati, mereaksi dan mengahasilkan puisi.

Kegiatan apresiasi dimulai dengan mengakrabkan siswa dengan puisi. Siswa dibimbing untuk melihat, mendengarkan dan merasakan keindahan yang ada dalam puisi secara langsung. Dengan merasakan pengalaman jiwa yang ada dalam sebuah puisi, akan muncul pengertian, penghargaan dan kepuasan batin dalam diri siswa. Dari pengetahuan di atas dapat dijadikan bekal siswa dalam mengapresiasi puisi.

Kenyataannya jumlah siswa yang mau membaca karya sastra masih sedikit. Selain karena siswa lebih tertarik pada untuk membaca karya sastra modern populer yang gaul, siswa juga lebih senang manikmati jenis sastra yang berupa media elektronik seperti audio visual dan sebagainya. Pengajaran apresiasi puisi menurut siswa adalah pembelajaran yang klasik dan monoton tidak modern yaitu dengan membaca karya sastra saja tanpa diiringi media yang membuat siswa menjadi tertarik.Musikalisasi puisi merupakan media yang digunakan untuk siswa agar mampu mengapresiasi karena musikalisasi puisi salah satu media yang memudahkan karya seni musik dengan puisi. Menurut Mulyadi (2016:259) musikalisasi merupakan kegiatan pembacakan puisi dengan cara dilagukan, diberi irama, atau diiringi musik yang sesui dengan isi puisi. Musikalisasi dapat membantu membangun suasana dan imajinasi kita dalam mengapresiasi puisi. Musikalisasi puisi yang merupakan dari media sastra elektronik, yaitu media audio yang berbentuk musikalisasi, puisi sebagai bentuk memusikkan atau melagukan puisi yang diiringi dengan instrument. Akan tetapi, media musikalisasi puisi ini merupakan sebuah wahana baru dalam mengembangkan media pembelajaran sekaligus sebagai adaptasi dari sastra tulis ke dalam sastra elektronik. Jadi, musikalisasi puisi ini merupakan media yang pengubahanya dari puisi menjadi sebuah musik.

Media ini juga diharapkan dapat menjadikan siswa untuk tidak meninggalkan budaya membaca karya sastra, akan tetapi musikalisasi ini merupakan awal sebagai motivasi agar siswa tertarik untuk menyukai karya sastra dan mempermudah untuk mengapresiasinya. Siswa tidak akan terjebak lagi dalam membaca puisi dan menulis saja, tetapi dengan media ini siswa akan mampu membandingkan antara pembacaan puisi yang berupa teks dengan musikalisasi puisi yang syarat dengan audio yang nyata, sehingga siswa mudah mengidentifikasi dan akan memperoleh hasil apresiasi yang maksimal.

Secara umum penelitian ini bertujuan untuk mengetahui seberapa besar peningkatan 
Nama Penulis : Judul Artikel

Website : https://jurnal.umj.ac.id/index.php/penaliterasiEmail : penaliterasi@umj.ac.id

apresiasi puisi siswa setelah menggunakan media musikalisasi puisi di SMAN 87 Jakarta kelas X.

\section{METODE PENELITIAN}

$\mathrm{J}$ enis Penelitian ini adalah Clasroom Action Research (CAR) atau penelitian tindakan kelas (PTK). Menurut Arikunto (2013:135) Penelitian tindakan kelas (Classroom action research), yaitu penelitian yang dilakukan oleh guru ke kelas atau di sekolah tempat ia mengajar dengan penekanan pada penyempurnaan atau peningkatan proses dan praksis pembelajaran. Peneliti harus mengadakan kerjasama secara kolaboratif dengan pihak lain yang masih menyangkut permasalahan yang akan diteliti. sedangkan menurut Tampubolon (2014:19) penelitian tindakan kelas adalah penelitian yang dilakukan oleh pendidik di dalam kelasnya sendiri melalui refleksi diri. Tujuannya adalah untuk memperbaiki kinerja sebagai pendidik, sehingga hasil belajar peserta didik menjadi meningkat dan secara sistem mutu pendidikan pada satuan pendidikan juga meningkat.

Subjek Penelitian tindakan ini adalah siswa kelas X MIPA 3 SMAN 87 Jakarta yang berjumlah 36 siswa dan seorang guru Bahasa Indonesia (yang sekaligus berperan sebagai kolaborator). Objek yang dijadikan sasaran penelitian adalah keaktifan siswa selama proses pembelajaran dan kompetensi apresiasi puisi siswa kelas X MIPA3 SMAN 87 Jakarta. Teknik yang digunakan untuk mengumpulkan data dalam penelitian ini meliputi, observasi, wawancara, kajian dokumen, dan tes.

Observasi ini dimaksudkan untuk memperoleh gambaran nyata kondisi pembelajaran apresiasi puisi di kelas serta keaktifan siswa selama pembelajaran berlangsung. Wawancara dilakukan terhadap siswa dan kolaborator. Wawancara dengan siswa dimaksudkan untuk menggali informasi dampak dari tindakan yang telah dilakukan guru dan untuk menggali pada kompetensi mana siswa masih mengalami kesulitan. Wawancara dengan kolaborator dimaksudkan untuk memperoleh masukan tentang pelaksanaan penerapan pendekatan pembelajaran, mengidentifikasi permasalahan-permasalahan yang timbul, dan merencanakan tindakan yang akan dilakukan. Kajian dokumen dilakukan peneliti bersama kolaborator terhadap Kurikulum, Rencana Pelaksanaan Pembelajaran (RPP) yang dibuat oleh guru, nilai yang telah diberikan oleh guru serta dokumen hasil pekerjaan siswa. Kajian dokumen berupa kurikulum, RPP dimaksudkan untuk menggali bagaimana perencanaan guru sebelum melakukan tindakan.

Kajian terhadap daftar nilai dimaksudkan untuk memperoleh data kompetensi siswa, dan kajian terhadap hasilhasil kerja siswa dilakukan untuk memperoleh data tentang kompetensi siswa sebelum dan setelah menerima tindakan. Kuesioner diberikan untuk menggali faktorfaktor penyebab mengapa kompetensi apresiasi puisi siswa rendah, menggali tanggapan siswa tentang pembelajaran yang telah diikutinya. Teknik tes digunakan untuk mengetahui kompetensi awal siswa sebelum diberi tindakan dengan media musikalisasi puisi dan tes akhir setiap siklus digunakan untuk mengetahui kompetensi siswa sesudah diberi tindakan dengan menghitung rata-rata 
dan persentase dengan rumus:

1. Rata-rata

$$
x=\frac{\sum x}{N}(\text { Sudjana, 2016:109) }
$$

$$
\begin{aligned}
& \text { Keterangan } \\
& x=\text { Nilai Rata-rata } \\
& \sum x=\text { Jumlah Semua Nilai (skor) } \\
& N=\text { Jumlah Anak (subjek) } \\
& x=\frac{\sum x}{N} \times 100 \%
\end{aligned}
$$

Teknik analisis data yang digunakan adalah teknik deskriptif komparatif. Peneliti membandingkan hasil sebelum penelitian dengan Efektivitas Pembelajaran Apresiasi Puisi melalui media musikalisasi. Membandingkan hasil pada akhir setiap siklus, membandingkan rata-rata kompetensi apresiasi puisi dan keaktifan siswa sebelum dan setelah tindakan siklus I, siklus II, dan siklus III.

\section{HASIL DAN PEMBAHASAN}

\section{Data Prasiklus}

Tahap pratindakan ini terdiri dari satu kali pertemuan dengan total dua jam pelajaran. Pelaksanaan pratindakan dilakukan pada hari Senin, 30 Oktober 2017 pukul 06.45 sampai dengan 08.15 WIB. Selama tahap pratindakan, peneliti dan guru melakukan observasi terhadap proses dan hasil pembelajaran. Siswa tampak belum siap memulai pembelajaran ketika guru dan peneliti masuk kelas tahap pratindakan. Sebagian besar siswa masih berdiri atau bergerombol di meja temannya sambil mengobrol. Ada beberapa siswa yang belum datang dan masih ada beberapa siswa yang duduk-duduk di luar kelas. Kemudian beberapa siswa langsung duduk di tempat duduk masing-masing saat melihat kedatangan guru dan peneliti, sementara beberapa lainnya masih meneruskan aktivitas mengobrol dengan temannya. Guru harus menegur siswa agar kembali ke tempat duduk masing-masing.

Pertemuan tahap pratindakan diisi dengan pemberian materi mengenai hal-hal yang berkaitan dengan puisi dan apresiasi puisi. Selanjutnya, Guru kemudian memberikan kesempatan pada siswa untuk bertanya mengenai hal-hal yang kurang dipahami berdasarkan materi yang telah disampaikan. Tidak ada siswa yang berani bertanya. Siswa justru hanya diam dan tidak memberikan respon. Karena tidak ada siswa yang bertanya, guru menganggap siswa sudah paham.

Setelah menjelaskan materi, guru menugasi siswa untuk mengapresiasi puisi melalui pemaknaan suatu puisi yang sudah ditentukan. Sebagian besar siswa mengeluh saat mengetahui tugas tersebut. Pada saat proses penugasan kondisi kelas menjadi tidak kondusif. Banyak siswa yang kebingungan saat memulai untuk menulis. Terlihat siswa kebingungan menentukan 
Nama Penulis : Judul Artikel

Website : https://jurnal.umj.ac.id/index.php/penaliterasiEmail : penaliterasi@umj.ac.id

makna puisi tersebut. Ada beberapa siswa mengobrol dengan teman sebangku ataupun teman dibangku lain tentang makna dari judul puisi dan makna keseluruhan puisi tersebut. Berdasarkan hasil observasi pratindakan, proses pembelajaran berjalan kurang baik. Saat guru menjelaskan materi, beberapa siswa justru ribut sendiri dengan siswa lain. Guru pun harus berkali-kali menegur siswa agar tenang. Sebagian siswa lain mendengarkan penjelasan guru dengan kurang semangat. Kurang kondusifnya kelas pada saat proses pembelajaran dan adanya siswa yang asyik mengobrol merupakan bukti bahwa siswa tidak serius mengikuti proses pembelajaran. Ketidak seriusan tersebut timbul karena kurangnya motivasi dan antusias siswa dalam mengikuti pembelajaran pada saat itu. Hal tersebut dapat dilatar belakangi oleh kurangnya pemanfaatan media dan proses pembelajaran yang kurang menarik serta menyenangkan.

Dalam tahap pratindakan ini, guru harus berkali-kali mengingatkan siswa untuk memperhatikan penjelasan guru. Hal tersebut dilakukan agar suasana kelas lebih kondusif dan pembelajaran dapat berjalan dengan lancar. Beberapa siswa bahkan harus dihampiri guru ke mejanya agar siswa fokus pada pembelajaran. Proses pembelajaran pun menjadi terganggu karena hal tersebut. Hasil keterampilan awal apresiasi puisi siswa siswa kelas X MIPA3 SMA 87 Jakarta dapat dilihat paada nilai rata-rata dan persentase berikut ini:

$$
\bar{x}=\frac{\sum x}{N}=\frac{1520}{35}=43,4
$$

2. Presentase

$$
\bar{x}=\frac{\sum x}{N} \times 100 \%=\frac{1520}{35} \times 100 \%=4,34 \%
$$

Berdasarkan hasil pratindakan di atas, diketahui bahwa skor rata-rata yang diperoleh siswa kelas X MIPA3 SMA Negeri 87 Jakarta tidak sesuai dengan harapan. Dari data tabel 4.2 diketahui bahwa skor rata-rata siswa secara keseluruhan baru mencapai 43,4. Skor rata-rata tersebut masih di bawah Kriteria Ketuntasan Minimal (KKM) mata pelajaran bahasa Indonesia dan kriteria keberhasilan penelitian, yaitu 75 . Hasil tes tersebut menunjukkan hasil yang kurang optimal dan menunjukkan bahwa keberhasilan apresiasi puisi siswa masih kurang dan berkategori rendah atau sangat kurang baik.

\section{Data Siklus 1}

\section{a. Perencanaan}

Perencanaan penelitian tindakan kelas siklus I ini disusun peneliti yang dibimbing oleh guru bahasa Indonesia, Bapak Drs. H. Urip Sukmadi. Perencanaan disusun bertujuan untuk mempersiapkan segala sesuatu yang akan dilakukan dalam penelitian tindakan kelas siklus I ini, sebagai upaya meningkatkan apresiasi puisi siswa kelas X MIPA3 SMA Negeri 87 Jakarta. Pada tahap perencanaan tindakan kelas siklus I ini, peneliti menyusun perencanaan dan mengadakan kegiatan sebagai berikut:

1) Menyusun Rencana Pelaksanaan Pembelajaran (RPP) dengan menggunakan media musikalisasi puisi yang akan digunakan oleh guru dalam pelaksanaan pembelajaran. RPP pada siklus I dengan kompetensi dasar Mengidentifikasi, suasana tema dan makna beberapa puisi yang terkandung 
dalam anatologi puisi yang diperdengarkan atau dibacakan.

2) Merumuskan alternatif tindakan yang akan dilaksanakan dalam upaya meningkatkan pembelajaran apresiasi puisi, yaitu menggunakan media musikalisasi puisi.

3) Menyusun langkah-langkah pelaksanaan pembelajaran yang akan dilaksanakan yang tertuang dalam RPP.

4) Menyiapkan materi apresiasi puisi.

5) Menyiapkan video musikalisasi puisi yang digunakan sebagai media dalam mengapresiasi puisi dalam bentuk VCD. Pada siklus pertama ini video musikalisasi yang dipilih untuk digunakan adalah video musikalisasi puisi Universitas Wiralodra "Dengan Puisi, Aku" karya Taufiq Ismail yang disusun oleh Dwi Setia Ningsih, Ika Rosdiana Rohim, Khusen Asibti, Nazhrotun Nadhiroh, Rahmat Suwito dan Suci Rahayu. Puisi tersebut bermakna bahwa penyair menceritakan kehidupannya lewat puisi. video musikalisasi ini dipilih karena makna yang terkandung di dalamnya dimana peniliti berharap ketika siswa disuruh untuk memaknai puisi tersebut pengetahuan siswa terhadap puisi meningkat, dan kegemaran siswa untuk menulis puisi juga meningkat karena makna puisi "Dengan Puisi, Aku" karya Taufiq Ismail ini menceritakan kejadian apa saja yang kita hadapi di kehidupan nyata dapat ditulis melalui puisi.

6) Mempersiapkan lembar observasi guru dan siswa
7) Mempersiapkan peralatan untuk pembelajaran dan dokumentasi kegiatan selama proses pembelajaran berlangsung seperti infocus, laptop, speaker, dan kamera.

b. Pelaksanaan Tindakan

Pelaksanaan tindakan dengan menerapkan media VCD musikalisasi puisi diharapkan dapat meningkatkan apresiasi puisi siswa kelas X MIPA3 SMA Negeri 87 Jakarta. Pelaksanaan tindakan dilakukan selama dua kali pertemuan sebagai berikut:

1) Pertemuan Pertama (Selasa, 31 Oktober 2017). Pertemuan pertama dengan menerapkan media VCD musikalisasi puisi dalam kegiatan pembelajaran apresiasi puisi. Pada pertemuan pertama ini pelaksanaan yang dilakukan peneliti adalah sebagai berikut:

Pada pertemuan pertama guru mempresentasikan materi tentang apresiasi puisi dan musikalisasi puisi. peneliti kembali menjelaskan pengertian puisi, unsur-unsur pembentuk puisi, pengertian apresiasi puisi, tingkat apresiasi puisi, pengertian musikalisasi puisi dan kelompok musikalisasi puisi. setelah materi dijelaskan peneliti memeberikan contoh beberapa video puisi yang sudah dimusikalisasikan. Selanjutnya, peneliti membagikan soal untuk menguji kemampuan apresiasi puisi melalui media musikalisasi puisi, sebelum siswa menjawab soal essay yang dibagikan siswa disuruh untuk membaca saol tersebut sebelum media musikalisasi puisi diputar setelah menunggu kurang lebih lima menit siswa disuruh untuk memperhatikan video musikalisasi puisi "Degan Puisi, Aku" karya 
Nama Penulis : Judul Artikel

Website : https://jurnal.umj.ac.id/index.php/penaliterasiEmail : penaliterasi@umj.ac.id

taufiq Ismail. Setelah video diputar siswa disuruh untuk mengerjakan tugas tentang makna puisi dalam video musikalisasi tersebut.

Selanjutnya peneliti membagi siswa menjadi lima kelompok dan menentukan ketua masing-masing kelompok. kelompok terdiri atas 7-8 siswa. membentuk sebuah lingkaran (duduk melingkari meja). Siswa dalam tiap kelompok membagi tugasnya masing-masing dan setiap kelompok berdiskusi untuk menentukan teks puisi apa yang akan dimusikalisasikan dan alat musik apa yang akan digunakan untuk mengiringi puisi tersebut.

2) Pertemuan kedua (Senin,6 November 2017).

Pada pertemuan kedua, kegiatan diawali dengan apersepsi tentang musikalisasi puisi. Dalam kegiatan pembelajaran ini siswa disuruh kembali duduk dengan kelompoknya masing-masing, peneliti membuat nomor undian untuk mempersentasikan hasil musikalisasi dari setiap kelompok. Setiap kelompok yang belum mendapat undian untuk maju dapat mempersiapkan hasil musikalisasinya. Saat kelompok mempersentasikan hasil musikalisasinya guru dan peneliti memberikan penilaian. Penilaian yang dilakukan berdasarkan panduan penilaian musikalisasi puisi.

\section{c. Pengamatan}

Selama melaksanakan tindakan dengan menggunakan media musikalisasi puisi dalam pembelajaran apresiasi puisi, peneliti melakukan pengamatan terhadap tindakan yang dilakukan pada siklus I yang dideskripsikan dalam lembar observasi dan catatan kolaborator. Hasil yang diperoleh dari pengamatan ini meliputi dampak tindakan terhadap proses pembelajaran (keberhasilan proses) dan dampak tindakan terhadap hasil pembelajaran (keberhasilan produk). Dampak dari tindakan keberhasilan proses dan keberhasilan produk dapat dideskripsikan sebagai berikut:

1) Pengamatan Proses

Dalam melakukan pengamatan proses pembelajaran, peneliti mengamati situasi kegiatan belajar siswa. Hal yang diamati dari situasi belajar siswa adalah perhatian, gairah belajar, keaktifan, dan suasana belajar. Pada saat dilakukan pembelajaran apresiasi puisi dengan menggunakan media musikalisasi puisi ini menunjukkan bahwa adanya perubahan sikap yang positif terhadap proses pembelajaran apresiasi puisi. Hal ini ditandai dengan perilaku siswa yang terlihat lebih aktif dan bersemangat dalam berdiskusi dan mengerjakan tugas yang diberikan oleh guru.

Pada pertemuan pertama, proses belajar mengajar memang masih kurang kondusif karena siswa masih belum memahami betul materi tentang apresiasi puisi dan bagaimana cara memusikalisasikan puisi. Pada saat tahap awal penerapan media musikalisasi puisi, terlihat adanya kendala pada penggunaan media, yaitu siswa mengalami kesulitan dalam hal memahami makna puisi. Hal ini dilatarbelakangi karena kesukaran siswa terhadap karya sastra. Guru kemudian mendatangi beberapa siswa untuk mengarahkan, membimbing, dan memotivasi siswa agar dapat memahami makna puisi yang ditugaskan. Meskipun demikian, terlihat adanya peningkatan 
situasi kegiatan siswa dalam pembelajaran apresiasi puisi pada kegiatan siklus I pertemuan pertama ini bila dibandingkan pada saat pratindakan.

2) Pengamatan Produk

Pengamatan produk dilakukan pada hasil memahami dan memusikalisasikan puisi.

a) Pengamatan produk pada pertanyaan kompetensi memenunjukkan bahwa terjadi peningkatan pemahaman kompetensi melalui memahamai makna puisi dilihat dari aspek-aspek pada pedoman penilaian sebagai berikut.

(1) Ketepatan jawaban Aspek ini mengalami peningkatan. Hal tersebut dapat dilihat dari makna puisi yang sudah di analisis siswa pemahaman judul puisi dan makna keseluruhan puisi sudah cukup baik dan tepat. (2) Keluasan dan keaslian jawaban mengalami peningkatan. Terlihat dari makna puisi yang dibuat oleh siswa. (3) Kelogisan argumentasi mengalami peningkatan. (4) Ketepatan makna dan kalimat mengalami peningkatan. (5) Gaya penuturan. Peningkatan apresiasi puisi juga dapat dilihat dengan adanya peningkatan skor ratarata pertanyaan kompetensi siswa dari saat pratindakan dengan tindakan siklus I. Dari hasil penelitian dapat diperoleh data skor rata-rata apresiasi puisi siswa melalui pertanyaan kompetensi siklus I sebagai berikut:

$$
\bar{x}=\frac{\sum x}{N}=\frac{2380}{32}=74,4
$$

2. Presentase $\bar{x}=\frac{\sum x}{N} \times 100 \%=\frac{2380}{32} \times 100 \%=7,44 \%$ rdasarkan rata-rata di atas diketahui bahwa skor rata-rata yang diperoleh pada siklus I mengalami peningkatan. Hasil tes tersebut menunjukkan hasil yang cukup baik. Dari tabel 4.3, diketahui bahwa dari 32 siswa yang hadir, 19 siswa dinyatakan sudah tuntas pada siklus I ini dan 13 siswa dinyatakan belum tuntas karena masih di bawah kriteria ketuntasan minimal. Dapat disimpulkan bahwa rata-rata tersebut menunjukkan bahwa keterampilan apresiasi siswa kelas X MIPA3 SMA Negeri 87 Jakarta dalam kategori cukup baik, skor rata-rata mengalami peningkatan.

Perolehan skor rata-rata keterampilan apresiasi puisi siswa pada pertanyaan komptensi melalui pemahaman makna puisi pada siklus I adalah 74.4 Skor rata-rata tersebut menandakan adanya peningkatan sebesar 31,1 poin dari skor rata-rata pratindakan. Jumlah nilai keseluruhan tiap aspek juga mengalami peningkatan.

\section{Data Siklus II}

a. Perencanaan

Siklus II dilaksanakan dalam empat tahap, yaitu perencanaan, tindakan, pengamatan, dan refleksi. Perencanaan dalam siklus II ini bertujuan untuk memperbaiki kekurangan yang masih terjadi dalam siklus I. Selain berupaya untuk memperbaiki dalam segi proses pembelajaran, dalam siklus II ini peneliti akan berupaya untuk memaksimalkan lagi kemampuan siswa dalam apresiasi puisi sehingga apresiasi puisi siswa akan semakin meningkat. Berdasarkan hasil refleksi pada 
Nama Penulis : Judul Artikel

Website : https://jurnal.umj.ac.id/index.php/penaliterasiEmail : penaliterasi@umj.ac.id

siklus I, rencana tindakan siklus II adalah sebagai berikut:

1. Peneliti melakukan koordinasi untuk siklus II dan memantapkan penerapan media musikalisasi puisi

2. Peneliti kembali mungulang materi. Penekanan kembali materi ini disusun berdasarkan kekurangan yang terdapat dalam apresiasi puisi dan tampilan musiklasiasi puisi siswa. Guru akan mengemukakan kesalahan-kesalahan yang dilakukan oleh siswa pada saat tes pertanyaan kompetensi dan tampilan kelompok. Guru akan mengambil contoh dari proses pembelajaran yang telah dilaksanakan pada siklus I. Dengan diberikan contoh langsung dengan penambahan ilustrasi siswa diharapkan lebih mengerti dan paham.

3. Peneliti memperbaiki media VCD musikalisasi yang sebelumnya video musikalisasi yang dipilih untuk digunakan adalah video musikalisasi puisi Universitas Wiralodra "Dengan Puisi, Aku" karya Taufiq Ismail yang disusun oleh Dwi Setia Ningsih, Ika Rosdiana Rohim, Khusen Asibti, Nazhrotun Nadhiroh, Rahmat Suwito dan Suci Rahayu. Puisi tersebut bermakna bahwa penyair menceritakan kehidupannya lewat puisi. Media yang sebelumnya akan diperbaiki dengan menambahkan waktu pembuka VCD dan menambahkan sedikit ilustrasi yang berbentuk gambar-gambar yang memudahkan siswa untuk lebih meningkatkan memahami makna puisi di apresiasi. Hal ini dilakukan agar siswa lebih fokus dan detail dalam mengamati media musikalisasi serta dapat lebih mengefisienkan waktu yang ada.

4. Peneliti dan guru menyusun langkahlangkah pelaksanaan pembelajaran apresiasi puisi

5. Peneliti menyiapkan instrumen penelitian yang berupa lembar observasi guru dan siswa sebagai alat untuk mendokumentasikan kegiatan pembelajaran.

b. Pelaksanaan

Pelaksanaan tindakan siklus II ini diharapkan dapat lebih meningkatkan keberhasilan proses dan keberhasilan produk dalam pembelajaran apresiasi puisi siswa kelas X MIPA3 SMA Negeri 87 Jakarta. Pelaksanaan tindakan dilakukan sebanyak satu kali pertemuan. Prosedur pelaksanaan tindakan pada siklus II dilaksanakan pada Selasa 7 November 2017. Seperti halnya pertemuan-pertemuan sebelumnya, pada pertemuan pertama siklus II ini guru mengawali pembelajaran dengan salam. Selanjutnya peneliti mengulas kembali kegiatan yang dilakukan pada siklus I, melakukan tanya jawab seputar kesulitan yang dialami siswa, dan menjelaskan kembali hal-hal yang perlu diperhatikan dalam mengapresiasi puisi. Dari hasil refleksi siklus I, diketahui bahwa skor apresiasi puisi siswa perlu ditingkatkan terutama pada aspek ketepatan jawaban, dan aspek ketetapan kata dan kalimat.

Oleh karena itu, peneliti menekankan kepada siswa untuk memperhatikan kedua aspek tersebut. Selain itu, peneliti mengingatkan siswa untuk memperhatikan video musikalisasi puisi agar dapat memahami makan puisi dengan sebaikbaiknya. Selanjutnya, peneliti 
menyampaikan kegiatan pembelajaran pada pertemuan hari itu, yaitu pembelajaran apresiasi puisi melalui pertanyaan kompetensi dan praktek musikalisasi puisi dengan menerapkan media VCD musikalisasi puisi siklus II. Untuk siklus II ini, guru menjelaskan bahwa media yang akan digunakan sama seperti siklus I dengan penambahan musik pembuka dan ilustrasi berupa gambar-gambar untuk memahami puisi yang dimusikalisasikan. Hal ini dilakukan agar masing-masing kelompok lebih fokus dalam mengamati media, lebih detail, dan waktu yang ada dapat lebih efisien.

Pembagian kelompok musikalisai tetap kelompok yang sudah diabgi di siklus I. Setiap kelompok kembali mengaransmen puisi yang akan dimusikalisasikan, dimana di siklus II ini setiap kelompok harus memperbaiki kesalahan-kesalahan yang dilakukan di siklus I. Kelompok pertama kembali memusikalisasikan puisi yang berjudul "Hampanya Hatiku" karya Rayendra Fairus, yang akan diringi alat musik suling. Kelompok kedua memusikalisasikan puisi yang berjudul "Padamu Jua" karya Amir Hamsah dengan menggunakan alat musik pianika. Kelompok ketiga memusikalisasikan puisi yang berjudul "Berjuanglah" yang diiringi alat musik gitar. Kelompok keempat memusikalisasikan puisi yang berjudul "Teman Baikku" yang diiringi alat musik pianika dan suling serta kelompok kelima memusikalisasikan puisi yang berjudul "Kerinduan" karya Niki Andini yang diiringi alat musik gitar.

Setelah semua siswa paham dengan tugasnya, kemudian guru membagikan lembar penilaian kepada masing-masing kelompok dan mempersilahkan masingmasing kelompok untuk menilai penampilan kelompok yang maju untuk menghindari tarjadi keributan saat kelompok lain tampil. Setelah itu setiap kelompk diberi sesi latihan dan persiapan dengan waktu 10 menit. Siswa menikmati kegiatan tersebut, hampir seluruh siswa fokus, bersungguh-sungguh, dan antusias. Waktu yang diberikan dapat dimanfaatkan secara optimal oleh masingmasing kelompok. Setiap kelompok menempati meja masing-masing yang sudah dipersiapkan sebelumnya. Kemudian guru menjelaskan tahap berikutnya, yaitu aspek penilaian tampilan musikalisasi puisi masing-masing kelompok. Siswa terlihat antusias dan bersemangat. Masing-masing kelompok terlihat langsung mengerjakan tugasnya masing-masing. Mereka terlihat lancar dan tidak merasa kesulitan dalam peraktek musikalisasi puisi. Suasana kelas juga lebih tenang dan kondusif bila dibandingkan pada saat pertemuan pertama siklus I. Waktu yang ada dapat dimanfaatkan siswa secara optimal.

c. Pengamatan

Peneliti dan guru kolaborator melakukan pengamatan terhadap proses dan hasil pembelajaran selama dilakukan tindakan kelas dengan menggunakan media musikalisasi puisi pada siklus II. Hasil yang diperoleh dari pemantauan ini meliputi dampak tindakan terhadap proses pembelajaran atau keberhasilan proses dan dampak tindakan terhadap hasil pembelajaran atau keberhasilan produk.

1) Pengamatan Proses

Dalam melakukan pengamatan proses 
Nama Penulis : Judul Artikel

Website : https://jurnal.umj.ac.id/index.php/penaliterasiEmail : penaliterasi@umj.ac.id

pembelajaran pada siklus II ini, peneliti mengamati situasi kegiatan belajar siswa dalam proses pembelajaran. Hal yang diamati dari situasi belajar siswa adalah perhatian, gairah belajar, keaktifan, dan suasana belajar

2) Pengamatan Produk

Pengamatan produk dilakukan pada hasil memahami dan memusikalisasikan puisi.

a) Pengamatan produk hasil apresiasi puisi siswa dalam pertanyaan kompetensi siswa pada siklus II. Hasil tindakan siklus II menunjukkan adanya peningkatan dibandingkan hasil siklus sebelumnya, baik dari keterampilan siswa dalam menjawab pertanyaan kompetensi maupun praktek musikalisasi puisi tugas kelompok maupun skor rata-rata. Pengamatan hasil dilakukan pada hasil pertanyaan kompetensi siswa dan tugas musikalisasi puisi kelompok.

Pengamatan hasil menunjukkan bahwa terjadi peningkatan keterampilan apresiasi puisi siswa dilihat dari aspekaspek pada pedoman penilaian. Penilaian terhadap hasil apresiasi puisi siswa dalam pertanyaan kompetensi siswa pada siklus II sebagai berikut:

(1) Aspek Ketepatan Jawaban. Hal tersebut dapat dilihat dari sebagian besar siswa sudah dapat memahami makna puisi yang diapresiasi sesuai judul teks puisi memiliki kaitan dengan makna puisi yang tulis siswa, pemahaman yang dituliskan dapat menggambarkan isi dari makna puisi yang diapresiasi. Pemaknaan isi tulisan juga sudah cukup baik sesuai dengan puisi yang diapresiasi. Puisi yang di maknai sudah cukup jelas dan tepat, (2) Aspek Keluasan dan Keaslian Jawaban. Keluasan dan keaslian jawaban mengalami peningkatan terlihat sebagian besar siswa sudah dapat (3) Aspek Kelogisan Argumentasi. (4) Aspek Ketepatan Kata dan Kalimat. (5) Gaya Penuturan.

Penilaian tersebut dapat diartikan siswa sudah memahami makna puisi memperhatikan aspek-aspek pada pedoman penilaian. Berdasarkan hasil penilaian dapat diperoleh data skor rata-rata apresiasi puisi pertanyaan kompetensi siklus II. Skor diperoleh dari penilaian, hasil skor siswa dalam pembelajaran apresiasi pada pertanyaan kompetensi terhadap pemahaman makna puisi siklus II dengan penerapan media musikalisasi dapat dilihat sebagai berikut:

1. Rata-rata

$$
\bar{x}=\frac{\sum x}{N}=\frac{2664}{32}=83,25
$$

2. Presentase

$$
\bar{x}=\frac{\sum x}{N} \times 100 \%=\frac{2664}{32} \times 100 \%=8,325 \%
$$

Berdasarkan table rata-rata diketahui bahwa skor rata-rata yang diperoleh mengalami peningkatan dibandingkan siklus sebelumnya. Hasil tes tersebut menunjukkan peningkatan hasil yang baik. Perolehan skor rata-rata apresiasi puisi siswa dalam pertanyan kompetensi memahmai makna puisi siklus II adalah 83,25. Skor rata-rata tersebut menandakan adanya peningkatan sebesar 8,88 dari skor rata-rata siklus I. Pada siklus II, seluruh siswa yang hadir dinyatakan tuntas karena nilai sudah di atas kriteria ketuntasan minimal dan ketuntasan keberhasilan 
penelitian. Jumlah niali tiap aspek juga mengalami peningkatan. Berdasarkan skor rata-rata tiap aspek yang dinilai dalam apresiasi puisi pertanyaan kompetensi dapat diketahui skor rata-rata dalam satu kelas sebagai berikut:

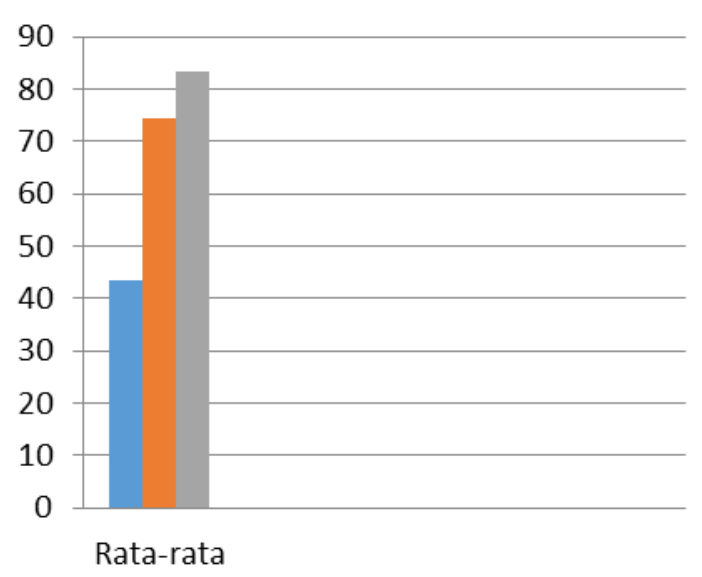

Gambar Diagram Perbandingan Skor Ratarata

Pratindakan, Siklus I, dan Siklus II

Berdasarkan gambar 4.6 dapat dilihat bahwa skor rata-rata pratindakan sebesar 43,4 , skor siklus I sebesar 74,4, skor siklus II sebesar 83,25. Oleh karena itu, dapat disimpulkan bahwa apresiasi puisi siswa mengalami peningkatan pada setiap siklus. Hal tersebut ditunjukkan oleh skor pratindakan menuju siklus I mengalami peningkatan sebesar 31, sedangkan siklus I menuju siklus II mengalami peningkatan sebesar 8.85 .

\section{Kesimpulan}

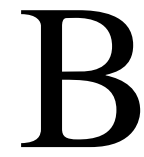
erdasarkan rumusan masalah dan hasil penelitian serta pembahasan dalam penelitian tindakan kelas dapat disimpulkan bahwa Sebelum dilakukan tindakan, pengetahuan dan apresiasi puisi siswa masih rendah. Kegiatan praktik apresiasi puisi belum dilaksanakan dengan baik dan perlu ditingkatkan. Penelitian tindakan kelas yang dilakukan sebagai upaya untuk peningkatan apresiasi puisi siswa kelas X MIPA3 SMA Negeri 87 Jakarta, dapat ditingkatkan dengan penggunaan media musikalisasi puisi. Penelitian tindakan kelas ini dilakukan dalam dua siklus. Namun, - Prasiklusebelumnya diadakan pratindakan terlebih - Siklus I dahulu hingga akhir siklus II.

- Siklus II Peningkatan ini dapat dibuktikan dengan peningkatan yang dialami siswa baik secara proses maupun secara produk. Kualitas pembelajaran apresiasi puisi meningkat dengan penggunaan media musikalisasi puisi. Pada saat dilakukan pembelajaran apresiasi puisi dengan menggunakan media musikalisasi ini menunjukkan bahwa adanya perubahan sikap yang positif terhadap proses pembelajaran apresiasi puisi. Pada siklus I, situasi kegiatan pada aspek perhatian sebagian besar siswa memperhatikan guru dalam proses pembelajaran. Pada aspek gairah belajar, siswa cukup antusias mengikuti pelajaran. Aspek keaktifan, siswa cukup aktif menyampaikan pertanyaan, pendapat, tanggapan atau komentar, dan bekerjasama dalam kelompok.

Secara keseluruhan hasil apresiasi puisi siswa sudah mulai bisa dipahami. Pada siklus II, proses pembelajaran siswa dalam apresiasi puisi menggunakan media musikalisasi puisi tersebut siswa semakin aktif berdiskusi dengan teman dan aktif bertanya kepada guru mengenai hal-hal yang kurang dimengerti. Selain itu, siswa juga lebih semangat dalam mengikuti pelajaran dan lebih senang dalam apresiasi puisi. 
Peningkatan keterampilan apresiasi puisi siswa dapat dilihat dari peningkatan skor ratarata siswa pada tahap pratindakan dengan pascatindakan.

Skor rata-rata siswa pada kompetensi pertanyaan sebelum diberi tindakan adalah 43,4, setelah diberi tindakan pada akhir siklus I skor rata-rata menjadi 74,4 . Skor rata-rata apresiasi puisi siswa pada akhir siklus II, yaitu 83,25. Sedangkan dalam praktek musikalisai puisi yang dilakukan di siklus I dan siklus II juaga mengalami peningkatan dimana skor rata-rata siklus I berjumlah 60 dan siklus II 88,8. Hal tersebut menunjukkan adanya peningkatan secara keseluruhan pada akhir siklus II. Terbukti bahwa penggunaan media musikalisasi puisi dinilai berhasil dan dapat meningkatkan apresiasi puisi siswa kelas X MIPA3 SMA Negeri 87 Jakarta.
Arikunto, Suharsimi. 2013. Prosedur Penelitian Suatu Pendekatan Praktik. Jakarta: Rineka Cipta.

Mulyadi, Yadi. 2016. Bahasa Indonesia untuk siswa SMA-MA/SMK-MAK Kelas X. Bandung: Yrama Widya.

Kosasih. 2008. Apresiasi Sastra Indonesia. Jakarta: Nobel Edumedia.

Salad Hamdy. 2015. Panduan Wacana dan Apresiasi Musikalisasi Puisi. Yogyakarta: Pustaka Belajar

Tampubolon, Saur. 2014. Penelitian Tindakan Kelas sebagai Penegembangan Profesi Pendidik dan Keilmuan. Jakarta: Erlangga

\section{Daftar Pustaka}


